\title{
Effects of Polycyclic Aromatic Hydrocarbon Pendant-Armed Ligands on the Catecholase Activity of Dinuclear Copper(II) Complexes
}

\author{
Marcos P. da Silva, ${ }^{a}$ Renata S. Heying, ${ }^{a}$ Leticia I. da Silva, ${ }^{a}$ Adailton J. Bortoluzzi, ${ }^{a}$ \\ Rosely A. Peralta ${ }^{\circledR} *, a$ and Ademir Neves ${ }^{\circledR} *, a$ \\ ${ }^{a}$ Laboratório de Bioniorgânica e Cristalografia (LABINC), Departamento de Química, \\ Universidade Federal de Santa Catarina, 88040-900 Florianópolis-SC, Brazil
}

\begin{abstract}
Herein, we present three new binuclear copper(II) complexes containing different polycyclic aromatic hydrocarbons, able to catalyze the oxidation of 3,5-di-tert-butylcathecol, a model substrate for catechol oxidase. The ligands and complexes were successful characterized in solid and solution states. The structure of $\mathbf{C 1}$ was determined by X-ray crystallography and it contains a $\left[\mathrm{Cu}_{2}{ }_{2}(\mathrm{~L} 1-\mu\right.$-phenoxo $\left.)(\mathrm{OAc})\left(\mathrm{H}_{2} \mathrm{O}\right)_{2}\right]$ unit, with two coppers in a pyramidal square geometry and a large distance of $3.715 \AA$ between the copper(II) centers. All complexes (C1, C2 and C3) were found to be effective catalysts in the oxidation of 3,5-di-tert-butylcathecol to its quinone and C1 provided the highest catalytic constants at the three $\mathrm{pH}$ values studied. In addition to their potential use as a biomimetic catalyst in catechol oxidation, the interaction of these complexes with deoxyribonucleic acid from calf thymus (CT-DNA) was also studied, and C3 showed the greatest affinity with nucleic acids.
\end{abstract}

Keywords: copper (II) dinuclear complexes, catecholase-like activity, polycyclic aromatic hydrocarbons, CT-DNA interaction studies

\section{Introduction}

The role of enzymes is of crucial importance in the development of many biological processes. It is known that a great advantage of enzymes in relation to model complexes, with regard to their action in catalysis, is the set of intermolecular forces, which causes a significant increase in the enzyme-substrate interaction. ${ }^{1,2}$

Copper ions can act in a series of redox reactions in many biological processes, such as electron transfer or the oxidation of several substrates. One example is the enzyme catechol oxidase (CO), which is a type-3 copper enzyme. In this enzyme, the dinuclear copper centers catalyze the oxidation of a variety of $o$-diphenols to the corresponding $o$-quinones, in a process known as catecholase activity. Inspired by the action of catechol oxidase, the development of new model compounds has opened up further possibilities, providing mechanistical information on the most desirable type of catalysis, for example, the oxidation of the model substrate 3,5-di-tertbutylcatechol (3,5-DTBC)..$^{3-9}$

*e-mail: rosely.peralta@ufsc.br; ademir.neves@ufsc.br
Copper oxidase biomimetics have been important in revealing the chemical roles of the metal centers and/or amino acid residues in the activation of dioxygen or the substrate during the biological oxidation processes. In the case of catechol oxidase, it has been proposed that the amino acids Phe 261, Ile 241 and His 244 at the active site of the enzyme contribute to the substrate binding, with hydrophobic interactions between the substrate and the amino acid residues. ${ }^{10}$

In this regard, the insertion of polycyclic aromatic hydrocarbons (PAHs) is an interesting option to improve the interaction between complex and substrate because, besides the contribution of intermolecular forces, the aptitude of these molecules in performing $\pi$-stacking interactions is also known, and this could contribute to nucleic acid binding. ${ }^{11-15}$

In recent studies, ${ }^{16,17}$ it has been shown that the insertion of PAHs in biomimetic complexes can increase the catalytic activity in the hydrolysis of phosphate esters. In addition, PAHs are reportedly excellent spectroscopic probes, due to the high value of their molar absorption constants. ${ }^{18,19}$

Herein, we compare the catalytic effects of a new series of dinuclear copper(II) complexes, $\mathbf{C 1}\left[\mathrm{Cu}_{2}^{\mathrm{II}}(\mathrm{L} 1)\right.$ (OAc) $](\mathrm{OAc}) \cdot 4 \mathrm{H}_{2} \mathrm{O} \mathbf{L 1}=2$-hydroxy-3-(((2-hydroxy5-methyl-3-((naphthalen-1-ylmethyl)(pyridin- 
3-ylmethyl)amino)benzyl)(pyridin-2-ylmethyl)amino) methyl)-5-methylbenzaldehyde; ${ }^{17} \mathbf{C 2}\left[\mathrm{Cu}_{2}{ }_{2}(\mathrm{~L} 2)(\mathrm{OAc})\right]$ (OAc) $) 7 \mathrm{H}_{2} \mathrm{O} \mathbf{L 2}=3-(((($ anthracen-9-ylmethyl)(pyridin3-ylmethyl)amino)methyl)-2-hydroxy-5-methylbenzyl) (pyridin-2-ylmethyl)amino)methyl)-2-hydroxy5-methylbenzaldehyde and $\mathbf{C 3}\left[\mathrm{Cu}^{\mathrm{II}}{ }_{2}(\mathrm{~L} 3)(\mathrm{OAc})\right]$ (OAc) $5 \mathrm{H}_{2} \mathrm{O} \mathbf{L 3}=2$-hydroxy-3-(((2-hydroxy-5-methyl3-(((pyren-1-ylmethyl)(pyridin-3-ylmethyl)amino) methyl)benzyl)(pyridin-2-ylmethyl)amino)methyl)5 -methylbenzaldehyde (Figure 1), on the oxidation of the model substrate 3,5-DTBC, through the insertion of different PAHs. As a further goal of the present study, we report on the interaction of the three complexes with deoxyribonucleic acid from calf thymus (CT-DNA).
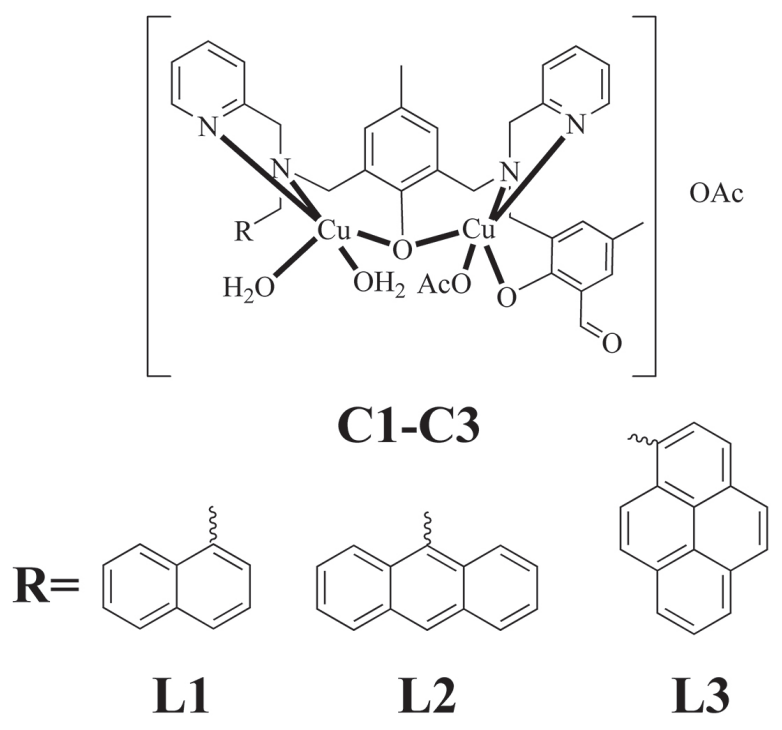

Figure 1. Compounds with the addition of PAHs.

\section{Experimental}

Materials, instrumentation and procedures

Spectra in the infrared region were obtained on a PerkinElmer spectrophotometer (Spectrum 100), in the region of 4000 to $450 \mathrm{~cm}^{-1}$. The samples were analyzed in $\mathrm{KBr}$ (spectroscopic grade) or by attenuated total reflectance (ATR). Electronic spectra in the region of $250-1000 \mathrm{~nm}$ were obtained for the ligands and complexes, on a Varian spectrophotometer (Cary 50 Bio). Analysis was performed using spectroscopic grade solvents in quartz cuvettes with an optical path length of $1.00 \mathrm{~cm}$. The molar absorption coefficients $(\varepsilon)$ are given in $\mathrm{L} \mathrm{mol}^{-1} \mathrm{~cm}^{-1}$. The redox behavior of the complexes was investigated, in dichloromethane solutions, by cyclic and square wave voltammetry using a Bioanalytical Systems, Inc. (BAS) potentiostat-galvanostat (model Epsilon). In the experiments carried out under argon, tetrabutylammonium hexafluorphosphate $\left(0.1 \mathrm{~mol} \mathrm{~L}^{-1}\right)$ was used as a support electrolyte for the measurements carried out in dichloromethane, and sodium perchlorate $\left(0.1 \mathrm{~mol} \mathrm{~L}^{-1}\right)$ was used for the experiments with methanol. The electrochemical cell consisted of three electrodes: working electrode (vitreous carbon); auxiliary electrode (platinum wire); and reference electrode $\left(\mathrm{Ag}^{\mathrm{O}} / \mathrm{Ag}^{\mathrm{I}}\right)$. For correction of the reference electrode, ferrocene (half-wave potential $\left(\mathrm{E}_{1 / 2}\right)$ vs. normal hydrogen electrode $(\mathrm{NHE})=400 \mathrm{mV}$ ) was used as an internal standard. ${ }^{20}$ The protonation constants for the complexes were determined by potentiometric titration in solutions prepared with bidistilled water, in the presence of $\mathrm{KMnO}_{4}$, and boiled to eliminate the presence of dissolved $\mathrm{CO}_{2}$. These experiments were carried out in a methanol/water solution $(1: 1 \mathrm{v} / \mathrm{v})$. A Metrohm automatic titrator (848 Titrino Plus) was used, coupled to a combined glass electrode $(\mathrm{Ag} / \mathrm{AgCl})$ with an aqueous $\mathrm{KOH}$ solution (ca. $0.100 \mathrm{~mol} \mathrm{~L}^{-1}$ ) as the titrant, which was standardized from the primary standard of potassium biphthalate. A stock solution of methanol/water $(1: 1 \mathrm{v} / \mathrm{v})$ containing $\mathrm{KCl}$ (ionic force of $\left.0.100 \mathrm{~mol} \mathrm{~L}^{-1}\right)$ and $\mathrm{HCl}\left(0.010 \mathrm{~mol} \mathrm{~L}^{-1}\right)$ was prepared to perform potentiometric titration measurements. Measurements were performed in a thermostated cell $\left(25.00 \pm 0.05{ }^{\circ} \mathrm{C}\right)$, under argon flow, to read the potential difference, which was subsequently converted to $\mathrm{pH}$. For this, $0.03 \mathrm{mmol}$ of each complex was dissolved in $25 \mathrm{~mL}$ of methanol and $25 \mathrm{~mL}$ of water was added to the system. The equilibrium constants were calculated with the BEST7 program, ${ }^{21}$ from the $\mathrm{p} K_{\mathrm{w}}$ value of 15.40 for the methanol/water system $(1: 1 \mathrm{v} / \mathrm{v}) .^{22}$ The distribution diagrams for the species present in solution as a function of $\mathrm{pH}$ were obtained with the program Species..$^{23}$ The melting points of the ligands were determined in a Büchi Melting Point B-540, with the qualitative insertion of the compounds in capillary tubes. Nuclear magnetic resonance spectra $\left({ }^{1} \mathrm{H}\right.$ and ${ }^{13} \mathrm{C}$ NMR) were obtained on a Bruker spectrophotometer (FT-NMR $200 \mathrm{MHz}$ ) or a Varian spectrophotometer (Mercury Plus $400 \mathrm{MHz}$ ). The samples were packed in a quartz tube of $5 \mathrm{~mm}$ and solubilized in $0.6 \mathrm{~mL}$ of deuterated solvent. Chemical shifts $(\delta)$ were expressed in parts per million (ppm) in relation to the internal residual peak used: the reference signal chosen for the ${ }^{1} \mathrm{H}$ NMR was referred to tetramethylsilane (TMS) in chloroform $(\delta=0.00 \mathrm{ppm})$ and for ${ }^{13} \mathrm{C}$ NMR the signal was referred to residual $\mathrm{CHCl}_{3}$ in $\mathrm{CDCl}_{3}(\delta=77.36 \mathrm{ppm})$. Mass spectra (electrospray ionization mass spectrometry (ESI-MS)) were obtained on a Bruker mass spectrometer (Amazon Ion Trap). The analysis was performed in positive ion detection mode, under $\mathrm{N}_{2}$ atmosphere with a flow of $180 \mathrm{~mL} \mathrm{~min}^{-1}$, capillary temperature between 150 and $200^{\circ} \mathrm{C}$ and capillary voltage between -400 and $-500 \mathrm{~V}$. The 
samples were injected by direct infusion of $20 \mathrm{~mL} \mathrm{~min}^{-1}$, sample concentration: $2 \times 10^{-4} \mathrm{~mol} \mathrm{~L}^{-1}$ in $\mathrm{MeOH}$.

\section{X-ray diffraction}

X-ray crystallography analysis was performed for $\mathbf{C 1}$. Diffraction data were collected on a Bruker diffractometer (APEX II DUO) using graphite-monochromated Mo radiation (Mo $\mathrm{K} \alpha \lambda=0.71073 \AA$ ) at a temperature of 200(2) K. Crystals of $\mathbf{C} 1$ showed poor scattering power above $2 \theta$ of $50^{\circ}$, and thus 393 frames were collected with an exposure time of $25 \mathrm{~s}$ per frame using $\phi$ and $\omega$ (rotation axis) scans with the APEX2 software. ${ }^{24}$ The intensities were integrated with the Bruker SAINT software package limited to a resolution of $0.76 \AA . .^{24}$ All data were corrected for Lorentz and polarization effects and for absorption using the SADABS multi-scan method. ${ }^{24}$ The structure was solved by dual space and refined with the full-matrix least-squares method using the SHELXL2018/1 program. ${ }^{25}$ All non-hydrogen atoms were refined with anisotropic displacement parameters. Hydrogen atoms were placed at their idealized positions with the distances and $\mathrm{U}_{\text {iso }}$ (isotropic displacement parameter) taken from the default of the refinement program. Hydrogen atoms of the water molecules were found from the Fourier difference map and treated with the riding model. The contribution to the structure factors attributed to the highly disordered solvate was removed using the PLATON/squeeze tool. ${ }^{26}$ After the squeeze procedure, the structure refinement converged to satisfactory crystallographic parameters, such as final $\mathrm{R}$ indices and goodness of fit. Selected crystallographic data are given in Table S1 (Supplementary Information (SI) section).

\section{Kinetic studies and interaction studies with CT-DNA}

Kinetic experiments for the oxidation of 3,5-DTBC were monitored spectrophotometrically by following the increase in the 3,5-di-tert-butylbenzoquinone (3,5-DTBQ) absorption band at $400 \mathrm{~nm}$ over time at different $\mathrm{pH}$ values and saturated $\mathrm{O}_{2}$ medium. . $^{3,27}$ The initial rates were obtained directly from the oxidation product concentration graph as a function of time. Dependence on the oxidation rate as a function of $\mathrm{pH}$ for substrate 3,5-DTBC was determined in the $\mathrm{pH}$ range of 3.5-10.0, thus obtaining the optimum $\mathrm{pH}$ for the reaction, measured at $25^{\circ} \mathrm{C}$. To examine the effect of the $\mathrm{pH}$ variation, substrate concentrations were kept constant $\left([\mathrm{C}]_{\text {cuvette }}=6.7 \times 10^{-5} \mathrm{~mol} \mathrm{~L}^{-1} ;[\mathrm{S}]_{\text {cuvette }}=6.7 \times 10^{-3} \mathrm{moL}^{-1}\right.$; $[\text { buffer }]_{\text {cuvette }}=3.3 \times 10^{-2} \mathrm{~mol} \mathrm{~L}^{-1}$, where $[\mathrm{C}]=$ complex concentration; $[\mathrm{S}]=3,5-\mathrm{DTBC}$ substrate concentration). The effect of substrate concentration was determined at the optimum $\mathrm{pH}$ for each complex. The substrate concentration effect was investigated similarly to the $\mathrm{pH}$ effect, maintaining the concentration of the complex and buffer constant in the reaction cell and varying the concentration of the substrate $\left([\mathrm{C}]_{\text {cuvette }}=6.7 \times 10^{-5} \mathrm{~mol} \mathrm{~L}^{-1}\right.$; $[\mathrm{S}]_{\text {cuvette }}$ varying from $8.3 \times 10^{-4}$ to $1.3 \times 10^{-2} \mathrm{~mol} \mathrm{~L}^{-1}$; $\left.[\text { buffer }]_{\text {cuvette }}=3.3 \times 10^{-2} \mathrm{~mol} \mathrm{~L}^{-1}\right)$. The mathematical treatment used to obtain the kinetic parameters was the nonlinear adjustment of the Michaelis-Menten equation. The formation of hydrogen peroxide in the oxidation reaction of 3,5-DTBC catalyzed by the complexes was detected by a modification of the iodometry method. ${ }^{28} \mathrm{~A}$ reaction mixture was prepared by mixing a stock solution of the complex, buffer and substrate solutions at the appropriate concentration and $\mathrm{pH}$. After $1 \mathrm{~h}$ of reaction, the solution concentration was halved by the addition of water and quinone was extracted with dichloromethane. The aqueous phase was acidified with sulfuric acid at $\mathrm{pH}=2$ to interrupt the oxidation reaction. This mixture was added to an aqueous solution of potassium iodide and 3 drops of an ammonium molybdate solution. In the presence of hydrogen peroxide, the following reaction occurs: $\mathrm{H}_{2} \mathrm{O}_{2}+2 \mathrm{I}^{-}+2 \mathrm{H}^{+} \rightarrow 2 \mathrm{H}_{2} \mathrm{O}+\mathrm{I}_{2}$. With an excess of iodide, the formation of the tri-iodide ion occurs $\left(\mathrm{I}_{2(\mathrm{aq})}+\mathrm{I}^{-} \rightarrow \mathrm{I}_{3}^{-}\right.$). This reaction is usually slow, but in acid medium and with the addition of ammonium molybdate it becomes almost instantaneous. The formation of $\mathrm{I}_{3}{ }^{-}$was monitored spectrophotometrically with the appearance of a characteristic band at $353 \mathrm{~nm}\left(\varepsilon=26000 \mathrm{~L} \mathrm{~mol}^{-1} \mathrm{~cm}^{-1}\right) .{ }^{28}$ Turnovers numbers (TON) were obtained monitoring the reaction between 3,5-DTBC and complexes $(\mathbf{C 1}, \mathbf{C} 2$ and $\mathbf{C 3})$ in 50:1 stochiometric rate, respectively, in $\mathrm{pH} 6.56$, between $36 \mathrm{~h}$. The determination of catalytic constants in absence of $\mathrm{O}_{2}$ were carried out under the same conditions of the reaction in saturated $\mathrm{O}_{2}$ medium at $\mathrm{pH}$ 6.56. Experiments to monitor the electronic spectra of the complexes in addition to the different amounts of CT-DNA (deoxyribonucleic acid from calf thymus solution in Tris(hydroxymethyl) aminomethane hydrochloride (TRIS-HCl) buffer 1:1; $189 \mu \mathrm{mol} \mathrm{L}^{-1}$ ) were performed in $50 \mathrm{mmol} \mathrm{L}^{-1}$ TRIS-HCl buffer ( $\mathrm{pH}$ 7.15) medium, with the initial proportion of methanol/water of $1 / 99(\mathrm{v} / \mathrm{v})$. The concentration of the CT-DNA solution was obtained by absorbance at $260 \mathrm{~nm}$ $\left(\varepsilon=6600 \mathrm{~mol}^{-1} \mathrm{~cm}^{-1}\right)$. An aliquot $(2 \mu \mathrm{L})$ of the CT-DNA solution was added to each cuvette containing the complex and the blank, and the spectra were obtained at each point. Absorbance values were corrected for dilution and the deoxyribonucleic acid (DNA) binding constant $\left(\mathrm{K}_{\mathrm{B}}\right)$ was obtained by adjusting the values using the following equation: [DNA] $/\left(\varepsilon_{\mathrm{a}}-\varepsilon_{\mathrm{f}}\right)=[\mathrm{DNA}] /\left(\varepsilon_{\mathrm{b}}-\varepsilon_{\mathrm{f}}\right)+1 /\left\{\mathrm{K}_{\mathrm{B}}\left(\varepsilon_{\mathrm{b}}-\varepsilon_{\mathrm{f}}\right)\right\}$, where $\varepsilon_{\mathrm{f}}$ and $\varepsilon_{\mathrm{b}}$ are the absorption coefficient of the free and completely bound complex, respectively, and $\varepsilon_{\mathrm{a}}$ the 
absorptivity after each addition. ${ }^{15}$ The final spectra were obtained by deducting the blank spectrum, obtained with CT-DNA, from the scans obtained with each of the complexes and different amounts of CT-DNA.

\section{General synthetic procedures}

The ligands and complexes were synthesized as shown in the SI section (Figures S1-S34). ${ }^{17,29,30}$ Reactants and solvents were purchased from Sigma-Aldrich (São Paulo, Brazil). The reactants 2-aminomethylpyridine and triethylamine were previously distilled, while other reactants and solvents were used without previous purification.

\section{Results and Discussion}

The ligands modified with PAHs were properly synthesized and characterized by ${ }^{1} \mathrm{H}$ NMR and infrared spectroscopy. Ligands L1, L2 and L3 were also submitted to melting point determination, mass spectrometry, elemental analysis and ${ }^{13} \mathrm{C}$ NMR spectroscopy.

The main bands in the infrared region for the ligands were attributed according to the literature. ${ }^{31}$ Very similar behavior was observed for all spectra, regarding the displacement and presence or absence of characteristic bands of the compounds of interest. The spectra, compiled in stages, for all ligands follow the behavior observed in Figures S28 to S30 (SI section). The spectra are arranged in such a way that their transmittances have arbitrary values (to aid the viewing). ${ }^{1} \mathrm{H}$ NMR spectra were collected for all compounds and are consistent with the proposed structures. The presence of PAHs can be observed on all spectra, leading to significant overlapping of the signals (Figures S20, S21, S23, S24, S26, S27, SI section). The fragments related to the base peaks found on the mass spectra for ligands $\mathbf{L} \mathbf{1}$ to $\mathbf{L} 3$ were characterized as the exact structures of the respective protonated ligands. The full mass spectra, as well as the expansions of these fragments superimposed on their respective isotopic distribution are given in the SI section (Figures S31 to S33).

The copper(II) binuclear complexes C1, C2 and C3 with the ligands L1, L2 and $\mathbf{L 3}$, respectively, were synthesized according to the reaction scheme given on Figure S34 (SI section), and the results are reported below. Elemental analysis results for ligand $\mathbf{L 1}, \mathbf{L} \mathbf{2}$ and $\mathbf{L 3}$, as for complexes $\mathbf{C 1}, \mathbf{C} \mathbf{2}$ and $\mathbf{C 3}$ are available in the end of each respective synthetical description on SI section.

\section{X-ray diffraction and infrared}

The molecular structure of $\mathbf{C} \mathbf{1}$ with atom labeling and selected bond distances and angles are shown in Figure 2. Crystal data are described by Table S1 (SI section). The structure is composed of a copper(II) dinuclear center with $\left[\mathrm{Cu}_{2}{ }_{2}(\mathrm{~L} 1)\left(\mathrm{H}_{2} \mathrm{O}\right)_{2}(\mathrm{OAc})\right]^{+}$cation, one acetate as counterion, and one molecule of water as crystallization solvate. According to the Addison parameters $(\tau)$ calculated for copper sites $\left(\tau_{5 \text {-Cu1 }}=0.004 ; \tau_{5 \text {-Cu2 }}=0.06\right)$, both metals show a geometry very close to square-pyramidal. ${ }^{32}$ The Jahn-Teller distortions can be observed from the $\mathrm{Cu} 1-\mathrm{O} 10$ and Cu2-O2W bond lengths (average of 2.298 and $2.446 \AA$, respectively), which are longer than the other bond distances involving the $\mathrm{Cu}$ (II) centers in $\mathbf{C 1}$. The presence of the acetate ion coordinated in monodentate form, with a bond distance of $\mathrm{Cu}-\mathrm{O} 61$ of $1.944 \AA$ and the lack of the second ligand in the bridge, commonly a counterion unit, can be noted. The distance between the copper centers in $\mathbf{C 1}$ is $3.715 \AA$, which is a long distance compared to complexes with structural similarities, connected with bridging ligands and even with catechol oxidase enzyme sites. ${ }^{9,33,34}$ Finally, the Cu1-O10 bond distance (2.297 $\AA$ ) at the apical coordination site of $\mathrm{Cu} 1$ is significantly longer when compared to the corresponding distance of Cu2-O10 (1.925 ̊). This result in considerable asymmetry of the $\mu$-phenoxo bridge, which is affected by electronic density at the metal centers, where $\mathrm{Cu} 1$ is coordinated by phenolate arm and terminal monodentate acetate ligand

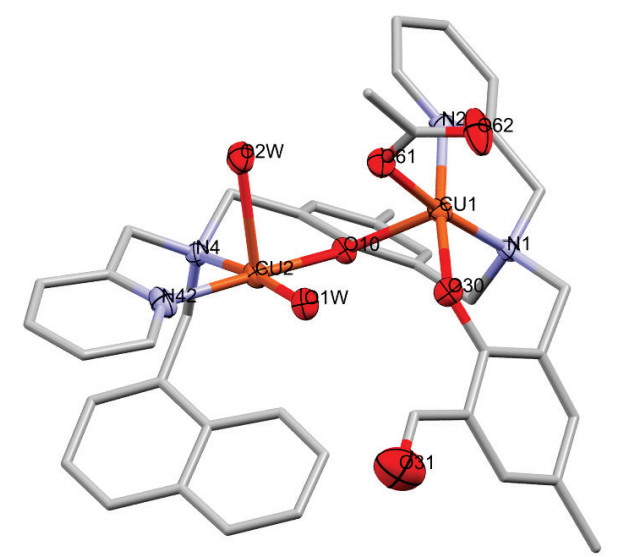

Figure 2. Molecular structure of C1. Hydrogen atoms are omitted, and carbon atoms are shown as stick for clarity. Only non-carbon atoms are plotted as ellipsoids (with $50 \%$ probability level). Selected bond lengths (̊): Cu1-O61 1.944(2); Cu1-O30 1.962(2); Cu1-N1 2.006(2); Cu1-N22 2.012(3); Cu1-O10 2.2976(18); Cu2-O10 1.9253(18); Cu2-O1W 1.974(2); Cu2-O2W 2.446(2); Cu2-N42 1.994(3); Cu2-N4 2.026(2); $\mathrm{Cu} 1-\mathrm{Cu} 2$ 3.7145(5). Selected angles (degree): O61-Cu1-O30 90.03(9); O61-Cu1-N1 173.26(9); O30-Cu1-N1 93.43(9); O61-Cu1-N22 92.49(10); O30-Cu1-N22 173.51(9); N1-Cu1-N22 83.48(10); O61-Cu1-O10 92.78(8); O30-Cu1-O10 96.92(8); N1-Cu1-O10 92.54(8); N22-Cu1-O10 88.93(8); O10-Cu2-O1W 90.90(8); O10-Cu2-N42 176.82(9); O1W-Cu2-N42 91.38(10); O10-Cu2-N4 94.72(9); O1W-Cu2-N4 173.22(9); N42-Cu2-N4 82.86(10); O10-Cu2-O2W 93.64(8); O1W-Cu2-O2W 88.33(8); N42-Cu2-O2W 88.64(9); N4-Cu2-O2W 95.08(8); C12-O10-Cu2 123.79(16); C12-O10-Cu1 112.33(15); Cu2-O10-Cu1 122.95(9); C32-O30-Cu1 127.08(19). 
whereas $\mathrm{Cu} 2$ center does not have other charged ligands in its coordination sphere.

The spectra for the infrared region of complexes C1, C2 and $\mathbf{C} 3$ show similarity to those related to the respective ligands. The axial stretching bands of the $\mathrm{C}=\mathrm{O}$ and $\mathrm{C}-\mathrm{O}$ bonds present in the counterion acetate unit from the starting salt are referenced in the literature. ${ }^{34,35}$ These are present on the spectra for the three complexes and overlap important bands in the regions between 1700 and $1350 \mathrm{~cm}^{-1}$. The spectra for the complexes, together with those for their respective ligands, are shown in Figures S35-S37 (SI section) and the values for the stretching are given in Table S2 (SI section).

\section{Solution studies}

The C1, C2 and C3 complexes presented similar spectral behavior in the UV-Vis region (Figure 3 ). The three complexes presented, at concentrations of $1 \times 10^{-2} \mathrm{~mol} \mathrm{~L}^{-1}$ in methanolic solution, a band in the region of 660-675-nm, related to the internal electronic transitions of type d-d typical of copper(II) systems (C1: $672 \mathrm{~nm}$, $\varepsilon=141 \mathrm{~L} \mathrm{~mol}^{-1} \mathrm{~cm}^{-1} ; \mathbf{C 2}: 661 \mathrm{~nm}, \varepsilon=252 \mathrm{~L} \mathrm{~mol}^{-1} \mathrm{~cm}^{-1}$; C3: $\left.671 \mathrm{~nm}, \varepsilon=204 \mathrm{~L} \mathrm{~mol}^{-1} \mathrm{~cm}^{-1}\right)$. ${ }^{4,28}$ For C1, at around $377 \mathrm{~nm}$, it is possible to observe a band with $\varepsilon$ close to $4000 \mathrm{~L} \mathrm{~mol}^{-1} \mathrm{~cm}^{-1}$ related to the charge-transfer transition of $\mathrm{Cu}-\mathrm{O}_{\text {phenolate }}$. This is consistent with the X-ray structure determined for $\mathbf{C} 1$ and the structures proposed for $\mathbf{C} 2$ and C3. Lastly, there are bands at higher energies with values of $\varepsilon\left(\mathbf{C 1}: 205 \mathrm{~nm}, \varepsilon=6.63 \times 10^{4} \mathrm{~L} \mathrm{~mol}^{-1} \mathrm{~cm}^{-1} ; \mathbf{C} 2: 204 \mathrm{~nm}\right.$, $\varepsilon=1.02 \times 10^{5} \mathrm{~L} \mathrm{~mol}^{-1} \mathrm{~cm}^{-1}, 256 \mathrm{~nm}, 1.16 \times 10^{5} \mathrm{~L} \mathrm{~mol}^{-1} \mathrm{~cm}^{-1}$; C3: $203 \mathrm{~nm}, \varepsilon=1.17 \times 10^{5} \mathrm{~L} \mathrm{~mol}^{-1} \mathrm{~cm}^{-1}, 239 \mathrm{~nm}$, $7.20 \times 10^{4} \mathrm{~L} \mathrm{~mol}^{-1} \mathrm{~cm}^{-1}, 266 \mathrm{~nm}, \varepsilon=3.82 \times 10^{4} \mathrm{~L} \mathrm{~mol}^{-1} \mathrm{~cm}^{-1}$, $277 \mathrm{~nm}, 3.90 \times 10^{4} \mathrm{~L} \mathrm{~mol}^{-1} \mathrm{~cm}^{-1}$ ), which are compatible with internal electronic $\pi-\pi^{*}$ transitions of PAHs. We assumed that the bands of pyridine were also covered by the PAH bands, due to the difference in the $\varepsilon$ magnitudes. To complement this evidence, scans of the respective ligands and of the free PAHs under similar experimental conditions were also obtained, to better distinguish the bands found. It was thus verified that the PAH bands overlap across most of the spectrum and that these units are present in all ligands and complexes. The UV-Vis spectra for compounds $\mathbf{C 1}$, C2 and C3 in methanol in lower concentrations are shown in Figure S38 (SI section). Comparisons with respective ligands L1, L2 and L3, the free PAHs under the same experimental conditions, and the spectra obtained with different concentrations are represented by Figures S39 to S44 (SI section). Table S3 (SI section) shows the maximum wavelengths for each band of each complex and the respective molar absorption coefficients $(\varepsilon)$. Solid-state
UV-Vis spectra of complexes C1, C2 and C3 (Figure S45, SI section) are similar to those obtained in $\mathrm{MeOH}$ solution, thus suggesting that the first-coordination sphere of the $\mathrm{Cu}$ centers is similar when the complexes are dissolved. Nevertheless, replacement of the weakly bound acetate by the solvent $(\mathrm{MeOH})$ should be considered as a being possible. ${ }^{4}$ ESI-MS data for $\mathbf{C 1}, \mathbf{C 2}$ and $\mathbf{C 3}$ in methanolic medium are in agreement with this proposal (vide infra).
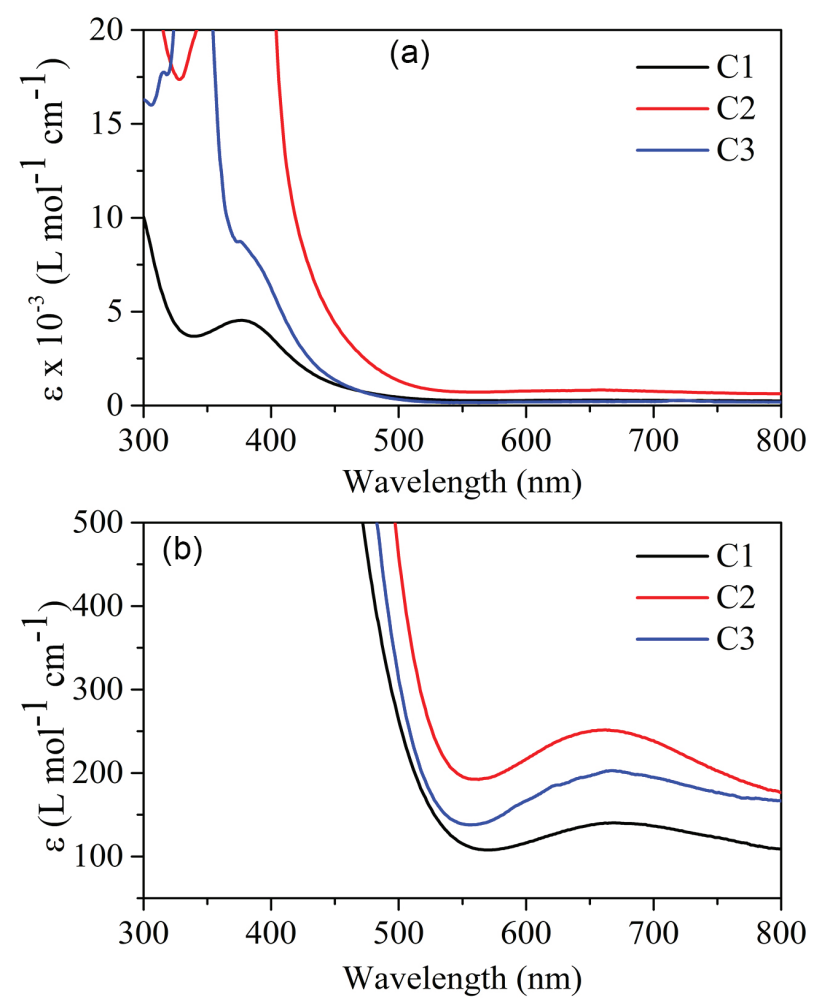

Figure 3. (a) UV-Vis spectra for compounds $\mathbf{C 1}, \mathbf{C} 2$ and $\mathbf{C 3}$ in methanol, $[\mathbf{C 1}]=1 \times 10^{-4} \mathrm{~mol} \mathrm{~L}^{-1} ;[\mathbf{C 2} ; \mathbf{C} 3]=5 \times 10^{-5} \mathrm{~mol} \mathrm{~L}^{-1}$ in 300 to $800 \mathrm{~nm}$ range. (b) UV-Vis spectra for compounds $\mathbf{C 1}, \mathbf{C 2}$ and $\mathbf{C 3}$ in methanol, [complex] $=1 \times 10^{-3} \mathrm{~mol} \mathrm{~L}^{-1}$; in range of 450 to $800 \mathrm{~nm}$.

Cyclic voltammetry carried out in dichloromethane revealed processes which were consistent with the proposed structure for binuclear complexes and can be assigned to and processes (Figure 4). 4,33,36 The values of cathodic peak potential $\left(\mathrm{E}_{\mathrm{pc}}\right)$ are similar to those previously reported for other copper(II) binuclear complexes, which indicates that the electronic sites are compatible with the proposed structure, as shown in Table 1. Square wave voltammetry results assisted in verifying the potential values, where the two processes mentioned above could be clearly observed. The square wave voltammograms were obtained in dichloromethane since, despite many attempts, in methanol medium the processes were not obtained with sufficient clarity and resolution (Figure S46, SI section). The same redox processes attributed to the copper(II) sites of three complexes in cyclic voltammetry were observed in the 
square wave experiments. The difference between the two cathodic processes of the copper(II) sites will be discussed in the evaluation of the kinetics. Electrochemical processes above $+0.5 \mathrm{~V}$ can be described as processes related to the oxidation of ligands. Table 1 provides a summary of the potentials in $\mathrm{mV}$ obtained for all complexes using the two techniques analyzed.

In the mass spectrometry (ESI-MS) carried out in methanolic medium, fragments were detected for complexes $\mathbf{C 1}\left(\mathrm{m} / z\right.$, calcd. for $\left[\mathrm{C}_{41} \mathrm{H}_{39} \mathrm{Cu}_{2} \mathrm{~N}_{4} \mathrm{O}_{4}\right]^{+}: 777.16$, found: 777.16; calcd. for $\left[\mathrm{C}_{42} \mathrm{H}_{41} \mathrm{Cu}_{2} \mathrm{~N}_{4} \mathrm{O}_{4}\right]^{+}$: 791.14,

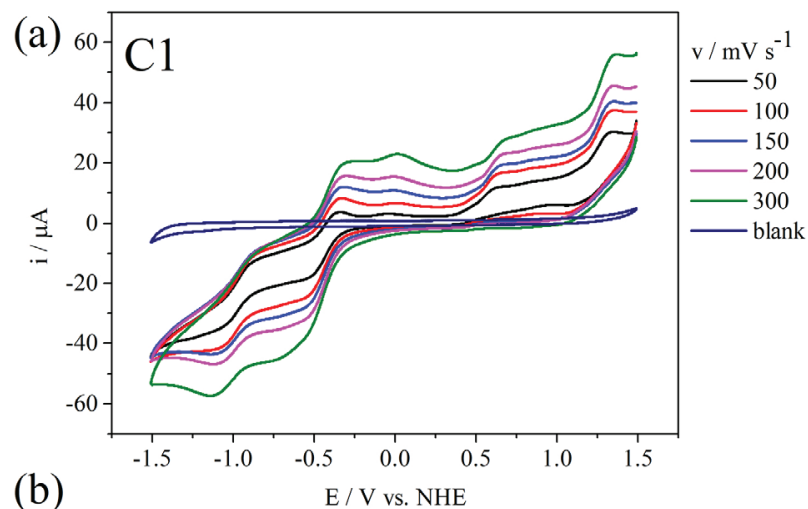

(b)
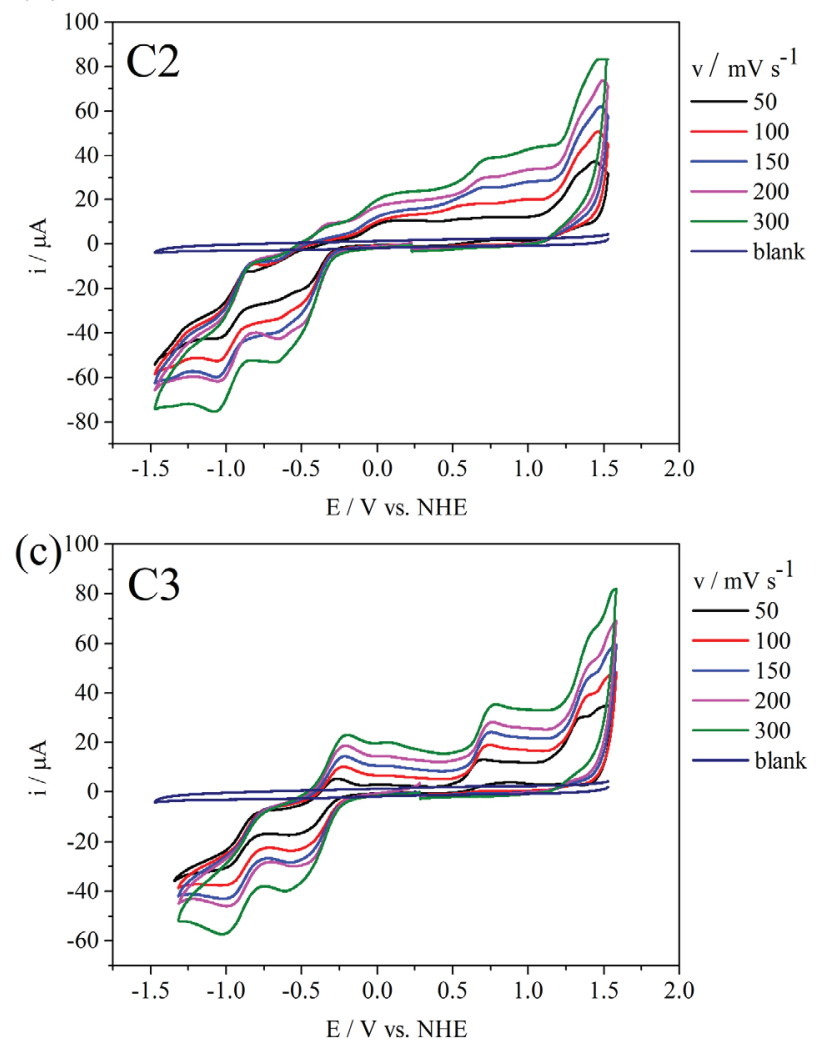

Figure 4. Cyclic voltammograms for (a) C1, (b) C2 and (c) C3 in dichloromethane. $[\mathbf{C 1}]=[\mathbf{C 2}]=[\mathbf{C 3}]=2.0 \times 10^{-4} \mathrm{~mol} \mathrm{~L}^{-1}$, electrolyte: $0.1 \mathrm{~mol} \mathrm{~L}^{-1} \mathrm{TBAPF}_{6}$; working electrode: vitreous carbon; reference electrode: $\mathrm{Ag} / \mathrm{AgI}$; counter electrode: platinum wire; scanning rate (v) between 50 and $300 \mathrm{mV} \mathrm{s}^{-1}$. The ferrocene $\left(\mathrm{Fc} / \mathrm{Fc}^{\mathrm{I}}\right)$ redox pair was used as the internal standard. ${ }^{20}$ found: 791.14; calcd. for $\left[\mathrm{C}_{43} \mathrm{H}_{41} \mathrm{Cu}_{2} \mathrm{~N}_{4} \mathrm{O}_{5}\right]^{+}:$: 819.17, found: 819.17), C2 (ESI-MS (ion-trap) $\mathrm{m} / \mathrm{z}$, calcd. for $\left[\mathrm{C}_{45} \mathrm{H}_{41} \mathrm{Cu}_{2} \mathrm{~N}_{4} \mathrm{O}_{4}\right]^{+}:$827.17, found: 827.17; calcd. for $\left[\mathrm{C}_{46} \mathrm{H}_{43} \mathrm{Cu}_{2} \mathrm{~N}_{4} \mathrm{O}_{4}\right]^{+}: 841.19$, found: 841.19; calcd. for $\left[\mathrm{C}_{47} \mathrm{H}_{43} \mathrm{Cu}_{2} \mathrm{~N}_{4} \mathrm{O}_{5}\right]^{+}:$869.18, found: 869.18; calcd. for $\left[\mathrm{C}_{45} \mathrm{H}_{47} \mathrm{Cu}_{2} \mathrm{~N}_{4} \mathrm{O}_{7}\right]^{+}:$881.20, found: 881.18) and $\mathbf{C 3}$ (ESI-MS (ion-trap) $\mathrm{m} / z$, calcd. for $\left[\mathrm{C}_{47} \mathrm{H}_{41} \mathrm{Cu}_{2} \mathrm{~N}_{4} \mathrm{O}_{4}\right]^{+}: 851.17$, found: 851.17; calcd. for $\left[\mathrm{C}_{48} \mathrm{H}_{43} \mathrm{Cu}_{2} \mathrm{~N}_{4} \mathrm{O}_{4}\right]^{+}:$: 865.19, found: 865.19; calcd. for $\left[\mathrm{C}_{47} \mathrm{H}_{47} \mathrm{Cu}_{2} \mathrm{~N}_{4} \mathrm{O}_{7}\right]^{+}$: 893.18, found: 893.18) that show similar systematic fragmentation. It was possible to observe the presence of three monovalent species in the three complexes, where the base peak contained the methoxide species and next were fragments with lower intensity containing acetate or hydroxide. Table S4 (SI section) shows a scheme of possible fragments found for C1, C2 and C3. The mass spectra for complexes $\mathbf{C 1}$ to $\mathbf{C 3}$ and the proposals for the fragments with their respective isotopic profiles are given below, as described by Figures S47 to S60 (SI section).

Assuming that a biomimetic compound could be used as an anticancer drug, as well as other complexes cited in the literature, ${ }^{37,38}$ fluorescence studies could be used for monitoring the drug delivery in a biological environment. In this regard, the fluorescence spectroscopy of ligands $\mathbf{L} \mathbf{1}$ to L3 revealed absorption and emission bands compatible with the presence of aromatic polycyclic structures. However, after the formation of the complexes these bands become strongly attenuated. With the presence of the paramagnetic centers of copper(II) ions, there is a significant amount of unpaired electrons that can contribute energetically to the system, causing electronic transitions between the ligand and the metal, decreasing the fluorescence intensity of the metal-ligand set when compared only to the ligand. The concentration used to obtain the spectra for the complexes was 10 times higher than that used for the ligands. Figure S61 (SI section) shows the fluorescence spectra obtained in methanol, comparing the ligands with the complexes in pairs.

The potentiometric titrations performed in $\mathrm{MeOH} / \mathrm{H}_{2} \mathrm{O}$ (1:1) medium revealed $5 \mathrm{p} K_{\mathrm{a}}$ values for the three systems, indicating relative structural similarity in solution between the complexes. Due to the presence of PAHs, one of the copper sites is free in one coordination position, which allows the binding of a counter-ion or solvent species, and this may explain the large number of $\mathrm{p} K_{\mathrm{a}}$ values for the system. The appearance of $\mathrm{p} K_{\mathrm{a} 1}$ can be assigned to acetate ion substitution with $\mathrm{H}_{2} \mathrm{O}$ molecules, while $\mathrm{p} K_{\mathrm{a} 2}$ is assigned to deprotonation of the terminal phenol. On the other hand, $\mathrm{p} K_{\mathrm{a} 3}, \mathrm{p} K_{\mathrm{a} 4}$ and $\mathrm{p} K_{\mathrm{a} 5}$ are related to the deprotonation of water molecules and formation of a hydroxo bridge ligand. Here, there is a notable difference between the 
Table 1. Values for potentials vs. NHE obtained for the redox processes of complexes $\mathbf{C 1}, \mathbf{C} 2$ and $\mathbf{C} 3$ in dichloromethane by cyclic and square wave voltammetry. $[\mathbf{C 1}]=[\mathbf{C 2}]=[\mathbf{C 3}]=2.0 \times 10^{-4} \mathrm{~mol} \mathrm{~L}^{-1}$, electrolyte: $0.1 \mathrm{~mol} \mathrm{~L}^{-1} \mathrm{TBAPF}_{6}$; working electrode: vitreous carbon; reference electrode: $\mathrm{Ag} / \mathrm{Ag}^{\mathrm{I}}$; counter electrode: platinum wire. Cyclic voltammetry scanning rate (v) between 50 and $300 \mathrm{mV} \mathrm{s}^{-1}$. Square wave parameters: pulse potential: $4 \mathrm{mV}$; amplitude: $25 \mathrm{mV}$; frequency: $25 \mathrm{~Hz}$. The ferrocene $\left(\mathrm{Fc} / \mathrm{Fc}^{1}\right)$ redox pair was used as the internal standard ${ }^{20}$

\begin{tabular}{|c|c|c|c|c|c|c|}
\hline \multicolumn{7}{|c|}{ E vs. NHE / mV } \\
\hline & & \multicolumn{3}{|c|}{ Cyclic voltammetry } & \multicolumn{2}{|c|}{ Square wave voltammetry } \\
\hline & & $\mathrm{Cu}^{\mathrm{II}} \mathrm{Cu}^{\mathrm{II}} \rightleftharpoons \mathrm{Cu}^{\mathrm{II}} \mathrm{Cu}^{\mathrm{I}}$ & $\mathrm{Cu}^{\mathrm{II}} \mathrm{Cu}^{\mathrm{I}} \rightleftharpoons \mathrm{Cu}^{\mathrm{I}} \mathrm{Cu}^{\mathrm{I}}$ & $\Delta \mathrm{E}_{(1,2)}$ & $\mathrm{Cu}^{\mathrm{II}} \mathrm{Cu}^{\mathrm{II}} \rightleftharpoons \mathrm{Cu}^{\mathrm{II}} \mathrm{Cu}^{\mathrm{I}}$ & $\mathrm{Cu}^{\mathrm{II}} \mathrm{Cu}^{\mathrm{I}} \rightleftharpoons \mathrm{Cu}^{\mathrm{I}} \mathrm{Cu}^{\mathrm{I}}$ \\
\hline \multirow{2}{*}{ C1 } & $\mathrm{E}_{\mathrm{pa}}$ & +16 & -279 & - & -171 & -749 \\
\hline & $\mathrm{E}_{\mathrm{pc}}$ & -748 & -1138 & 390 & -212 & -744 \\
\hline \multirow{2}{*}{$\mathrm{C2}$} & $\mathrm{E}_{\mathrm{pa}}$ & - & - & - & -546 & -959 \\
\hline & $\mathrm{E}_{\mathrm{pc}}$ & -636 & -1062 & 426 & -360 & -943 \\
\hline \multirow{2}{*}{$\mathrm{C3}$} & $\mathrm{E}_{\mathrm{pa}}$ & - & -190 & - & -284 & -882 \\
\hline & $\mathrm{E}_{\mathrm{pc}}$ & -564 & -1003 & 439 & -463 & -975 \\
\hline \multirow{2}{*}{$\mathrm{A}^{4}$} & $\mathrm{E}_{\mathrm{pa}}$ & - & - & - & - & - \\
\hline & $\mathrm{E}_{\mathrm{pc}}$ & -615 & -917 & 302 & - & - \\
\hline \multirow{2}{*}{$B^{33}$} & $\mathrm{E}_{\mathrm{pa}}$ & - & - & - & - & - \\
\hline & $\mathrm{E}_{\mathrm{pc}}$ & -750 & -1040 & 290 & - & - \\
\hline \multirow{2}{*}{$D^{36}$} & $\mathrm{E}_{\mathrm{pa}}$ & - & - & - & - & - \\
\hline & $E_{p c}$ & -890 & -1110 & 220 & - & - \\
\hline
\end{tabular}

NHE: normal hydrogen electrode; A: $\left[\mathrm{Cu}_{2}^{\mathrm{II}}(\mathrm{L})(\mu-\mathrm{OAc})\right]\left(\mathrm{ClO}_{4}\right)_{2}, \mathrm{~L}=1,3$-bis[bis(2-pyridylmethyl)amino]propanolate; $\mathrm{B}:\left[\mathrm{Cu}_{2}{ }_{2}\left(\mathrm{HLdtb}^{\mathrm{I}}\right)\left(\mu-\mathrm{OCH}{ }_{3}\right)\right]\left(\mathrm{ClO}_{4}\right)_{2}$, $\mathrm{HLdtb}=\{2$-[N,N-bis(2-pyridylmethyl)aminomethyl]-6-[N',N'-(3,5-di-tert-butylbenzyl-2-hydroxy)(2-pyridylmethyl)]aminomethyl $\}$-4-methylphenol; D: $\left[\mathrm{Cu}_{2}(\mathrm{Hbtppnol}) \mathrm{CH}_{3} \mathrm{COO}\right]\left(\mathrm{ClO}_{4}\right)_{2}, \mathrm{Hbtppnol}=N$-(2-hydroxybenzyl)- $N, N^{\prime}, N^{\prime}$-tris(2-pyri-dylmethyl)-1,3-diaminopropan-2-ol; $\Delta \mathrm{E}_{(1,2)}:\left(\mathrm{E}_{\mathrm{pcl}}-\mathrm{E}_{\mathrm{pc} 2}\right)$; $\mathrm{E}_{\mathrm{pa}}$ : anodic peak potential; $\mathrm{E}_{\mathrm{pc}}$ : cathodic peak potential.

values moving from $\mathbf{C} 1$ to $\mathbf{C 2}$ and $\mathbf{C 3}$, which indicates that the presence of the larger condensed rings of the anthracene and pyrene units aids the stability of the system, increasing all $\mathrm{p} K_{\mathrm{a}}$ values, most notably that of $\mathrm{p} K_{\mathrm{a} 5}$. The species charts (Figure S62, SI section), a general proposal suggested for equilibrium (Figure 5) and a table showing the $\mathrm{p} K_{\mathrm{a}}$ values (Table 2) proposed for compounds $\mathbf{C 1}$ to $\mathbf{C} \mathbf{3}$ are given below.

\section{Kinetics and DNA interaction}

As possible models of the enzyme catechol oxidase, the oxidative potential of the complexes $\mathbf{C 1}$ to $\mathbf{C} \mathbf{3}$ was tested, using the model substrate 3,5-DTBC. One of its products is 3,5-DTBQ, which shows an absorption maximum at $400 \mathrm{~nm}$ and $\varepsilon=1570 \mathrm{~L} \mathrm{~cm}^{-1} \mathrm{~mol}^{-1} \cdot 3,4,27$

Firstly, $\mathrm{pH}$ optimization studies were conducted to identify the $\mathrm{pH}$ at which the reaction occurs most favorably. All values for initial rates $\left(\mathrm{v}_{\mathrm{o}}\right)$, and consequently for observed constants $\left(\mathrm{k}_{\mathrm{obs}}\right)$, were obtained by deducting the value for the reaction with the catalyst from that for the reaction without catalyst (auto-oxidation). The results of this experiment, given in Figure 6, reveal that there are three regions of higher activity and thus these $\mathrm{pH}$ conditions were chosen to evaluate the effect of varying the substrate.

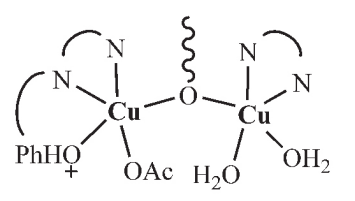<smiles></smiles><smiles>OC1(OC(O)(O)N2CCNC2(O)O)C#CCC#CCN1</smiles><smiles>OC1(O)NCCN1C(O)(O)C1(O)NCCN1</smiles><smiles>OC1(O)NCCN1C(O)(O)C1(O)NCCN1</smiles><smiles>C#CCN1CCNC1(O)OC1(O)NCC1(O)O</smiles>

$D$

E

Figure 5. Proposal for the equilibrium in solution observed for complexes C1, C2 and C3 (see Figure S62, SI section). 
Table 2. Values for the $\mathrm{p} K_{\mathrm{a}} \mathrm{s}$ obtained for complexes $\mathbf{C 1}, \mathbf{C 2}$ and $\mathbf{C 3}$

\begin{tabular}{lccc}
\hline & $\mathbf{C 1}$ & $\mathbf{C 2}$ & $\mathbf{C 3}$ \\
\hline $\mathrm{p} K_{\mathrm{a} 1}$ & $3.74 \pm 0.15$ & $4.52 \pm 0.18$ & $4.32 \pm 0.17$ \\
$\mathrm{p} K_{\mathrm{a} 2}$ & $5.06 \pm 0.20$ & $5.32 \pm 0.21$ & $5.26 \pm 0.21$ \\
$\mathrm{p} K_{\mathrm{a} 3}$ & $5.45 \pm 0.22$ & $6.03 \pm 0.24$ & $5.86 \pm 0.24$ \\
$\mathrm{p} K_{\mathrm{a} 4}$ & $6.56 \pm 0.26$ & $7.89 \pm 0.32$ & $7.81 \pm 0.31$ \\
$\mathrm{p} K_{\mathrm{a} 5}$ & $9.24 \pm 0.37$ & $11.23 \pm 0.45$ & $11.40 \pm 0.46$ \\
\hline
\end{tabular}

$\mathrm{p} K_{\mathrm{a}}=-\log K_{\mathrm{a}}$.
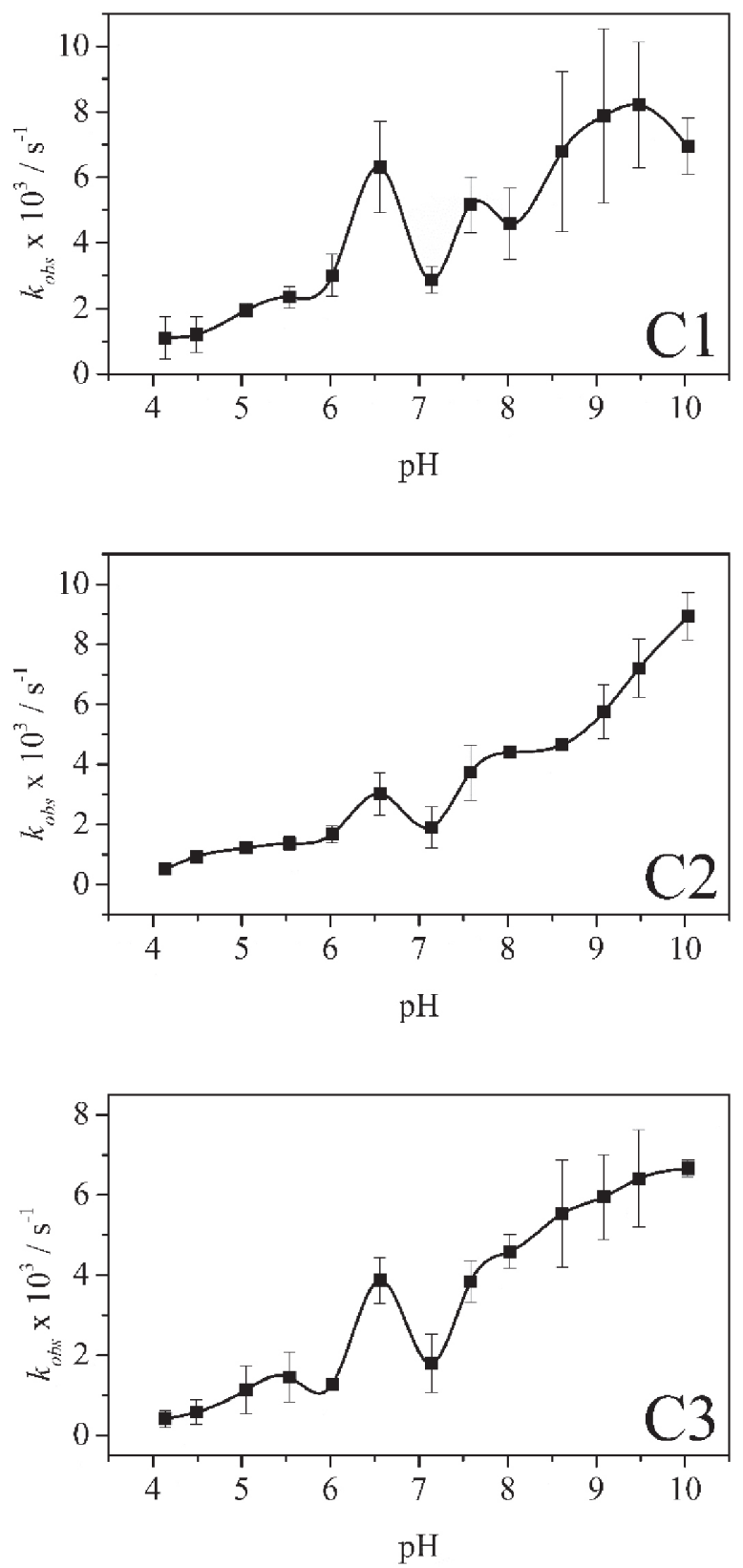

Figure 6. Graphs showing $\mathrm{k}_{\mathrm{obs}}$ as a function of $\mathrm{pH}$ for the oxidation reaction of substrate 3,5-DTBC catalyzed by complexes C1, C2 and C3 in $\mathrm{MeOH} / \mathrm{H}_{2} \mathrm{O}(97: 3)$ at $25{ }^{\circ} \mathrm{C}$ under the following conditions: $[\mathrm{C}]_{\text {cuvette }}=6.67 \times 10^{-5} \mathrm{~mol} \mathrm{~L}^{-1} ;[3,5-\mathrm{DTBC}]_{\text {cuvette }}=6.67 \times 10^{-3} \mathrm{~mol} \mathrm{~L}^{-1}$; $[\text { buffer }]_{\text {cuvente }}=0.033 \mathrm{~mol} \mathrm{~L}^{-1}$ without ionic strength.
The curves showing the effect of $\mathrm{pH}$ have the same profile for all complexes, with basically three $\mathrm{pH}$ values associated with maximum activity: $\mathrm{pH} 6.5, \mathrm{pH} 7.5$ and $\mathrm{pH}>9$. Unfortunately, on the chart profile it was not possible to adequately fit the $\mathrm{pH}$ versus $\mathrm{k}_{\mathrm{obs}}$ values and, thus, the kinetic $\left(\mathrm{p} K_{\mathrm{a}}\right)$ values were not extracted. However, the profiles of the kinetic and potentiometric curves indicate, observing the potentiometric data, that species containing terminal hydroxides are responsible for the maximum activity at the respective $\mathrm{pH}$ values. This initially suggests that species that have the highest catalytic activity should have significant structural similarities.

The results for the effect of substrate concentration at $\mathrm{pH}$ values of $6.56,7.58$ and 9.09 showed that at $\mathrm{pH}=7.58$ the catalytic efficiency values for the three complexes are similar (Figure 7). However, at $\mathrm{pH}=6.56$, the catalytic efficiency of $\mathbf{C 1}$ is twice as high as that of $\mathbf{C 2}$, a trend repeated on comparing $\mathbf{C 2}$ with $\mathbf{C 3}$ (Table 3). These results suggest that, in this case and at this $\mathrm{pH}$, there is an energy barrier that prevents the association of the substrate with the complex, perhaps due to the steric effects of PAH groups and/or the $\mathrm{p} K_{\mathrm{a}}$ of deprotonation of one of the aquo ligands. They also highlight the isolated catalytic constant $\left(\mathrm{k}_{\mathrm{cat}}\right)$ value for $\mathbf{C} \mathbf{1}$, which makes the catalytic efficiency of this complex the best of those tested. This induces this species to allow, under these conditions, not only changes in its association, but also some kind of interaction that aids the active center in catalysis. The lower $\mathrm{p} K_{\mathrm{a}}$ values for $\mathbf{C} \mathbf{1}$ also corroborate this hypothesis, since $\mathbf{C} \mathbf{1}$ revealed higher catalytic activity than $\mathbf{C} 2$ and $\mathbf{C} 3$ at the three $\mathrm{pH}$ values studied. Table 3 also compares the values of catalytic constants of selected copper(II) complexes, towards the oxidation of 3,5-DTBC substrate model, which shows that the results are compatible with recent literature data. ${ }^{4,22,39-50}$

In resume, as $\mathrm{pH} 6.56$ showed best results of catalytic constants on the oxidation of 3,5-DTBC model, the determination of turnover numbers and the catalytic constants were obtained in this same $\mathrm{pH}$ value. The lower values of the reaction in absence of $\mathrm{O}_{2}$ compared to the reaction in saturated $\mathrm{O}_{2}$ medium reveals the importance of $\mathrm{O}_{2}$ in the catalytic cycle. The turnovers numbers presented a decrease as the size of PAH inserted increases, which suggests that for these complexes in this catalytic system, it is easier to regenerate the catalyst when it contains smaller pendant groups, as seen in $\mathbf{C} 1$. These results are shown in Table S5 (SI section).

Other factors may be associated with the catalysis efficiency, such as steric match or intermolecular forces, but the value of the electrochemical parameter $\Delta \mathrm{E}_{(1,2)}=\left(\mathrm{E}_{\mathrm{pc} 1}-\mathrm{E}_{\mathrm{pc} 2}\right)$ calculated for the complexes also confirms the systematic trend in values obtained for 

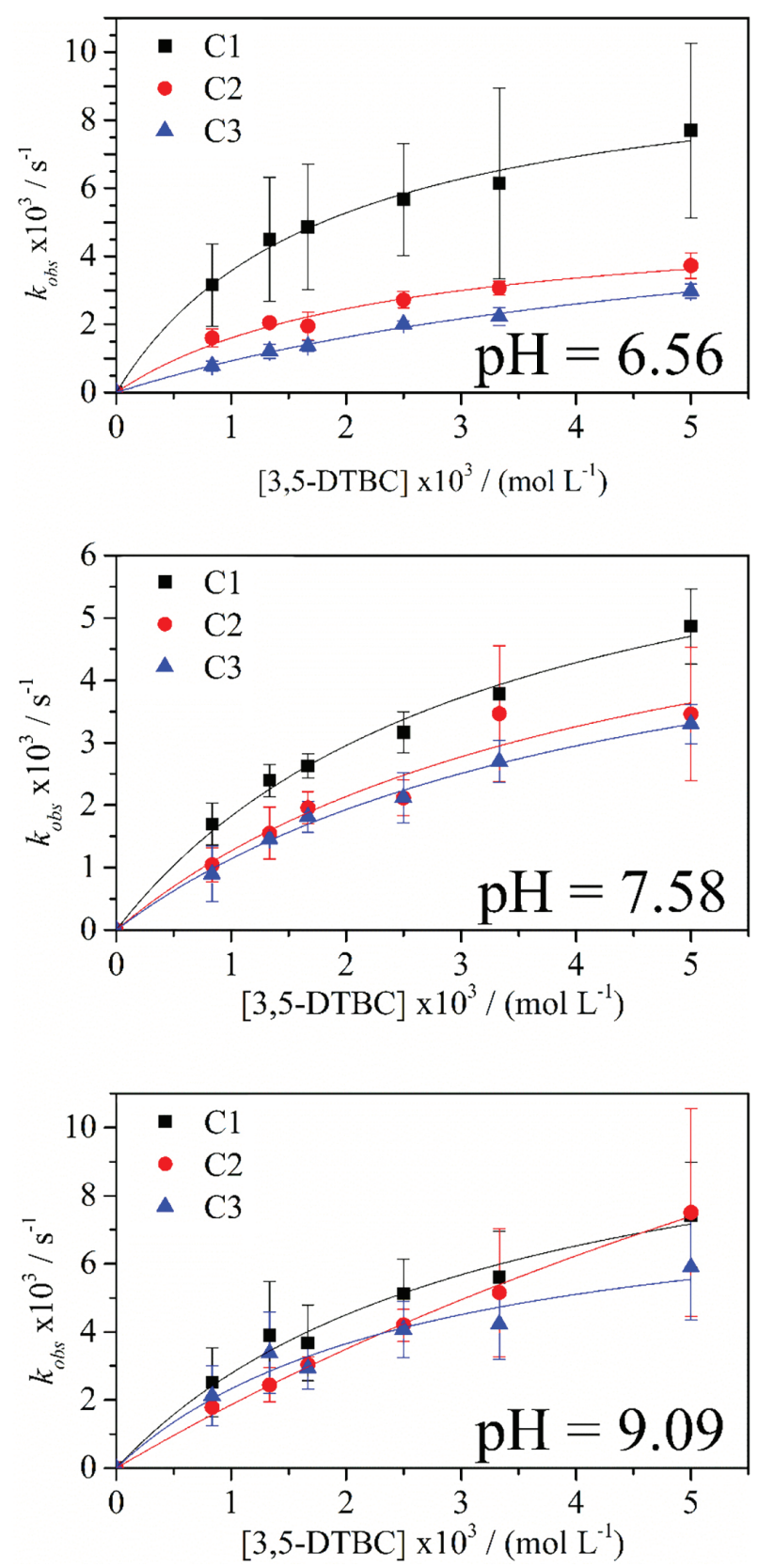

Figure 7. Graphs showing $\mathrm{k}_{\mathrm{obs}}$ as a function of substrate concentration for hydrolysis reaction of 3.5-DTBC catalyzed by complexes C1, C2 and $\mathbf{C 3}$ in $\mathrm{MeOH} / \mathrm{H}_{2} \mathrm{O}(97: 3)$ at $25^{\circ} \mathrm{C}$ under the following conditions: $\mathrm{pH}=6.56 ; 7.58$ and $9.09 ;[\mathrm{C}]_{\text {final }}=6.67 \times 10^{-5} \mathrm{~mol} \mathrm{~L}^{-1}$; $[3,5-\mathrm{DTBC}]_{\text {final }}=8.33 \times 10^{-4}$ to $5 \times 10^{-3} \mathrm{~mol} \mathrm{~L}^{-1}$; [buffer $]=0.03 \mathrm{~mol} \mathrm{~L}^{-1}$ without ionic strength.

catalytic efficiency (Table 1): for $\mathbf{C 1}, \Delta \mathrm{E}_{(1,2)}=390 \mathrm{mV}$ which, together with the best values for the catalytic constants, indicates that this type of catalysis shows a better performance, with lower differences between the potentials of the metal centers (Figure 8). It can thus be assumed that the mechanism involved is closer to a two-electron transfer rather than a one-electron intermediate. Based on the literature, ${ }^{4,33,36}$ the values of $\Delta \mathrm{E}_{(1,2)}$ obtained for $\mathbf{C 1}$, $\mathbf{C 2}$ and $\mathbf{C 3}$ could initially lead these complexes to show
Table 3. Values for the catalytic constants obtained for the complexes C1, $\mathbf{C} 2$ and $\mathbf{C 3}$ at $\mathrm{pH}$ values of 6.56, 7.58 and 9.09

\begin{tabular}{lcccc}
\hline $\mathrm{pH}$ & Complex & $\mathrm{k}_{\text {cat }} \times 10^{3} / \mathrm{s}^{-1}$ & $\begin{array}{c}\mathrm{K}_{\mathrm{m}} \times 10^{3} / \\
\left(\mathrm{mol} \mathrm{L}^{-1}\right)\end{array}$ & $\begin{array}{c}\mathrm{k}_{\text {cat }} / \mathrm{K}_{\mathrm{m}} / \\
\left(\mathrm{L} \mathrm{mol}^{-1} \mathrm{~s}^{-1}\right)\end{array}$ \\
\hline & $\mathbf{C 1}$ & $10.09 \pm 0.64$ & $1.82 \pm 0.28$ & $5.54 \pm 0.44$ \\
6.56 & $\mathbf{C 2}$ & $5.31 \pm 0.52$ & $2.31 \pm 0.49$ & $2.30 \pm 0.71$ \\
& $\mathbf{C 3}$ & $6.51 \pm 0.60$ & $6.01 \pm 0.85$ & $1.08 \pm 0.25$ \\
\hline & $\mathbf{C 1}$ & $7.78 \pm 0.69$ & $3.27 \pm 0.54$ & $2.38 \pm 0.60$ \\
7.58 & $\mathbf{C 2}$ & $6.84 \pm 1.83$ & $4.39 \pm 1.98$ & $1.56 \pm 1.12$ \\
& $\mathbf{C 3}$ & $6.27 \pm 0.54$ & $4.50 \pm 0.65$ & $1.39 \pm 0.32$ \\
\hline & $\mathbf{C 1}$ & $11.84 \pm 1.44$ & $3.26 \pm 0.74$ & $3.63 \pm 1.27$ \\
9.09 & $\mathbf{C 2}$ & $28.81 \pm 5.46$ & $14.48 \pm 3.42$ & $1.99 \pm 0.85$ \\
& $\mathbf{C 3}$ & $8.47 \pm 1.40$ & $2.63 \pm 0.89$ & $3.22 \pm 1.14$ \\
\hline 8.0 & $\mathrm{~A}^{4}$ & 2.8 & 0.86 & 3.3 \\
8.5 & $\mathrm{E}^{22}$ & 5.33 & 2.02 & 1.84 \\
n.d. & $\mathrm{F}^{39}$ & 4.72 & $1.8 \pm 0.2$ & 2.61 \\
n.d. & $\mathrm{G}^{40}$ & 0.001 & 5.1 & $2.0 \times 10^{-4}$ \\
\hline $\mathrm{A}$ & & &
\end{tabular}

A: $\left[\mathrm{Cu}_{2}{ }_{2}(\mathrm{~L})(\mu-\mathrm{OAc})\right]\left(\mathrm{ClO}_{4}\right)_{2}, \mathrm{~L}=1,3$-bis[bis(2-pyridylmethyl) amino]propanolate; E: $\left[\mathrm{Cu}_{2}{ }_{2}(\mathrm{~L})(\mu-\mathrm{OAc})\left(\mathrm{H}_{2} \mathrm{O}\right)\right]\left(\mathrm{ClO}_{4}\right)_{2} \cdot \mathrm{H}_{2} \mathrm{O}$, $\mathrm{L}=\left(2-\left(N, N\right.\right.$-bis(2-pyridylmethyl)aminomethyl)-6-( $N^{\prime}, N^{\prime}$-(2-hydroxy5-methylbenzyl)(2-pyridylmethyl))aminomethyl)-4-methyl]phenol; F: $\left[\mathrm{Cu}_{2}(\mathrm{~L})(\mu-\mathrm{OH})\right], \mathrm{L}=N^{1}, N^{3}-\operatorname{bis}(2,2-\operatorname{di}(1 H$-pyrazol-1-yl)ethyl)2-hydroxyisophthalamide; $\mathrm{G}$ : $\left[\mathrm{Cu}_{2} \mathrm{Cl}_{3}(\mathrm{~L})\right], \mathrm{L}=2$,6-bis-[(2-hydroxyethylimino)-methyl]-4-methyl phenol]; n.d.: not determined; $\mathrm{k}_{\text {cat }}$ : catalytic constant; $\mathrm{K}_{\mathrm{m}}$ : Michaelis-Menten constant; $\mathrm{k}_{\mathrm{cat}} / \mathrm{K}_{\mathrm{m}}$ : catalytic efficiency.

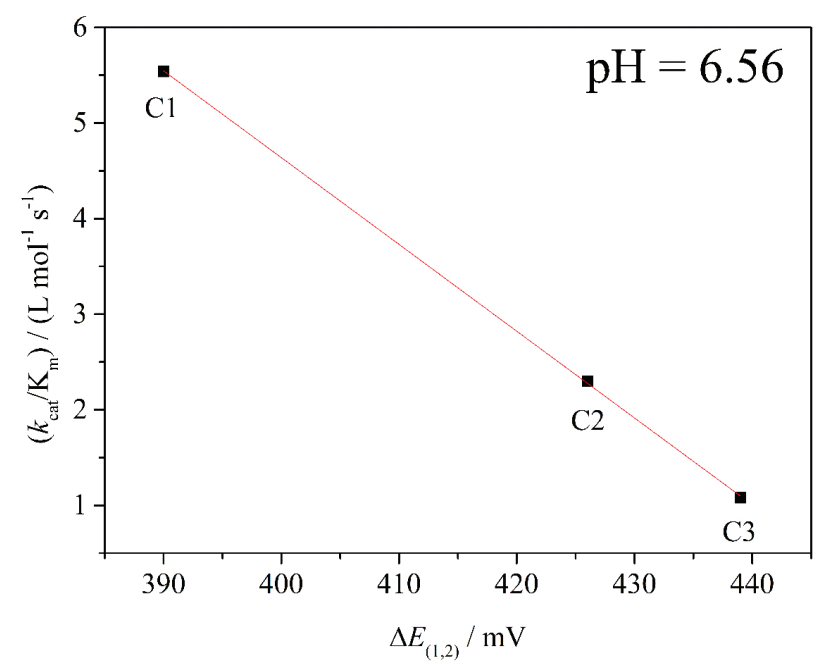

Figure 8. Correlation between $\Delta \mathrm{E}_{(1,2)}$ and $\mathrm{k}_{\mathrm{cat}} / \mathrm{K}_{\mathrm{m}}$ values obtained for $\mathbf{C 1}$, $\mathbf{C} 2$ and $\mathbf{C 3}$ at $\mathrm{pH}=6.56$.

a very poor performance in the oxidation of 3,5 -DTBC. ${ }^{4}$ However, allied to the presence of the PAHs and with one more coordination position available at the softer copper site, these complexes showed good results, particularly with regard to the $\mathrm{k}_{\text {cat }}$ and the reduction in the $\mathrm{p} K_{\mathrm{a}}$ values. ${ }^{4,33,36}$ The iodometric tests revealed that for all complexes there was the formation of $\mathrm{H}_{2} \mathrm{O}_{2}$, suggesting that the reaction between substrate and $\mathrm{O}_{2}$ has a 1:1 stoichiometry. 


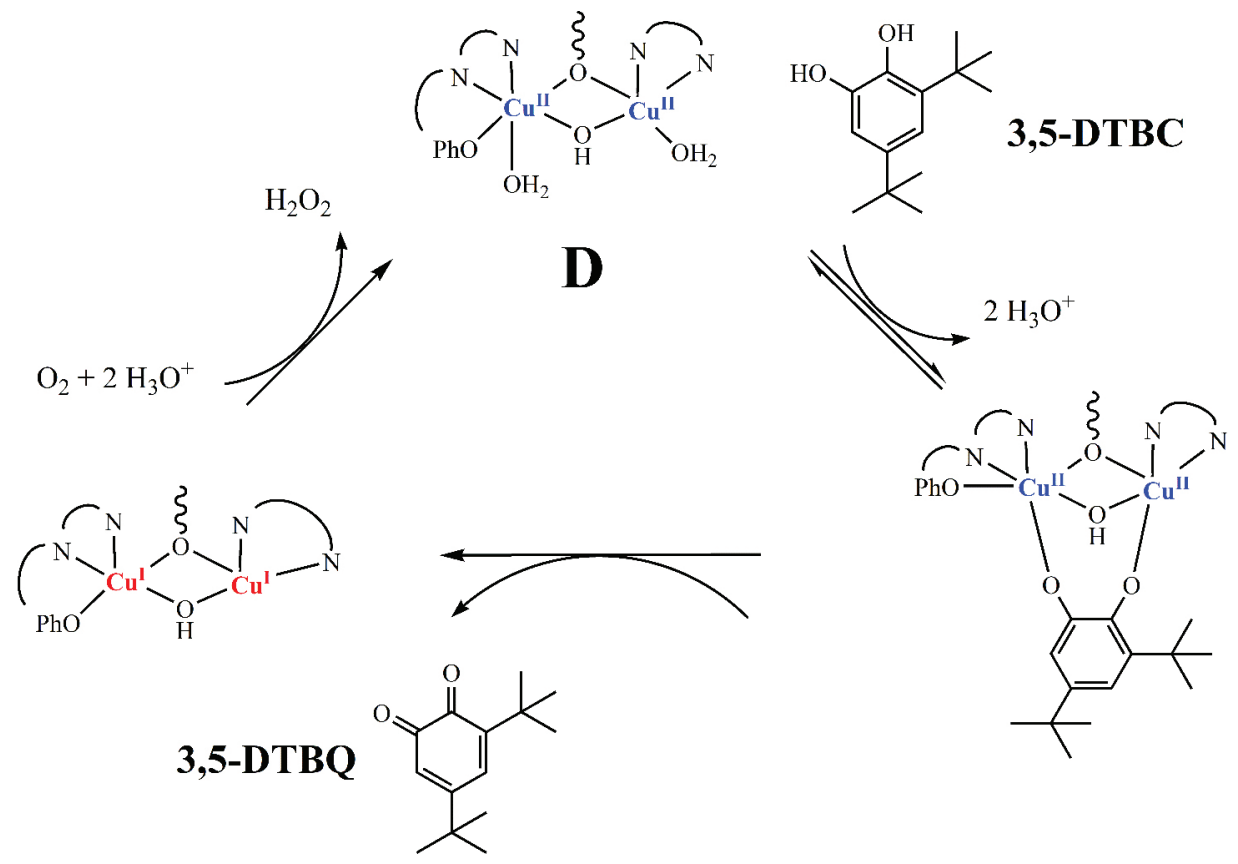

Figure 9. Proposal for the mechanism of oxidation of 3,5-DTBC catalyzed by $\mathbf{C 1}, \mathbf{C} 2$ and $\mathbf{C} 3$ in pH 6.56.

So far, with these evidences and in agreement with most binuclear copper(II) complexes, we propose a mechanism of oxidation of 3,5-DTBC mediated by complexes $\mathbf{C 1}, \mathbf{C} 2$ and C3 (Figure 9). The specie D (see Figure 5) has the highest abundance at $\mathrm{pH} 6.56$ and thus, it was chosen as the initial species in the proposed mechanism. The 3,5-DTBC binds to the softer copper(II) site and, in another step, coordinates in the other metal center with release of $\mathrm{H}_{3} \mathrm{O}^{+}$. Next, the redox process occurs, with the reduction of the copper centers through the simultaneous transfer of two electrons, releasing the product 3,5-DTBQ. Finally, in the presence of $\mathrm{O}_{2}$ at the observed $\mathrm{pH}$, the metal centers are oxidized with the release of $\mathrm{H}_{2} \mathrm{O}_{2}$ and regenerating the catalyst.

To evaluate the interaction of complexes $\mathbf{C 1}, \mathbf{C} 2$ and C3 with CT-DNA, successive CT-DNA additions were performed in solutions containing $1 \times 10^{-5} \mathrm{~mol} \mathrm{~L}^{-1}$ of the complexes in TRIS-HCl buffer $\mathrm{pH}=7.15$. The results show hypochromism in relation to bands of the complex with the addition of CT-DNA (Figure 10). The values obtained for $\mathrm{K}_{\mathrm{B}}$ calculated by linearization of the equation proposed by Pyle $^{40}$ show that complex $\mathbf{C 3}$ has the highest affinity for interaction with DNA. ${ }^{51}$ The values obtained are in the same order of magnitude compared with those for other copper(II) complexes reported in the literature ${ }^{51-56}$ and this suggests that all complexes can interact with CT-DNA in an intercalative way (Table 4).

\section{Conclusions}

The results reported herein demonstrate that in biomimetic synthesis, especially in the case of binuclear complexes, not only the secondary effects but also steric and thermodynamic effects should be considered. In the cases examined in this study, a higher catalytic efficiency was observed for complex $\mathbf{C} \mathbf{1}$ in the oxidation of the model 3,5-DTBC, but complex $\mathbf{C 3}$ presented the highest affinity with CT-DNA. On the other hand, although the catalytic constants for $\mathbf{C} \mathbf{1}$ were not as high, this is a very promising model, as it achieved better results, at the lowest $\mathrm{pH}$ tested, than most similar copper(II) complexes. ${ }^{4,22,39-50}$ Lastly, in agreement with data published in the literature, this system of structurally related complexes shows that a difference of $\Delta \mathrm{E}_{1 / 2}$ in the reduction potential of the $\mathrm{Cu}^{\mathrm{II}}$ centers plays an important role in the simultaneous two-electron oxidation of 3,5-DTBC. ${ }^{4}$ Thus, we were unable to detect any intermediate containing a peroxide species. As regards future perspectives, new compounds are being synthesized by reacting the aldehyde group with other substituents. This is expected to lead to a better understanding of the system and possibly an investigation of the effects of the second sphere of coordination.

\section{Supplementary Information}

Crystallographic data (excluding structure factors) for the structures in this work were deposited in the Cambridge Crystallographic Data Centre as supplementary publication number CCDC 2001022. Copies of the data can be obtained, free of charge, via https://www.ccdc.cam. ac.uk/structures/. 

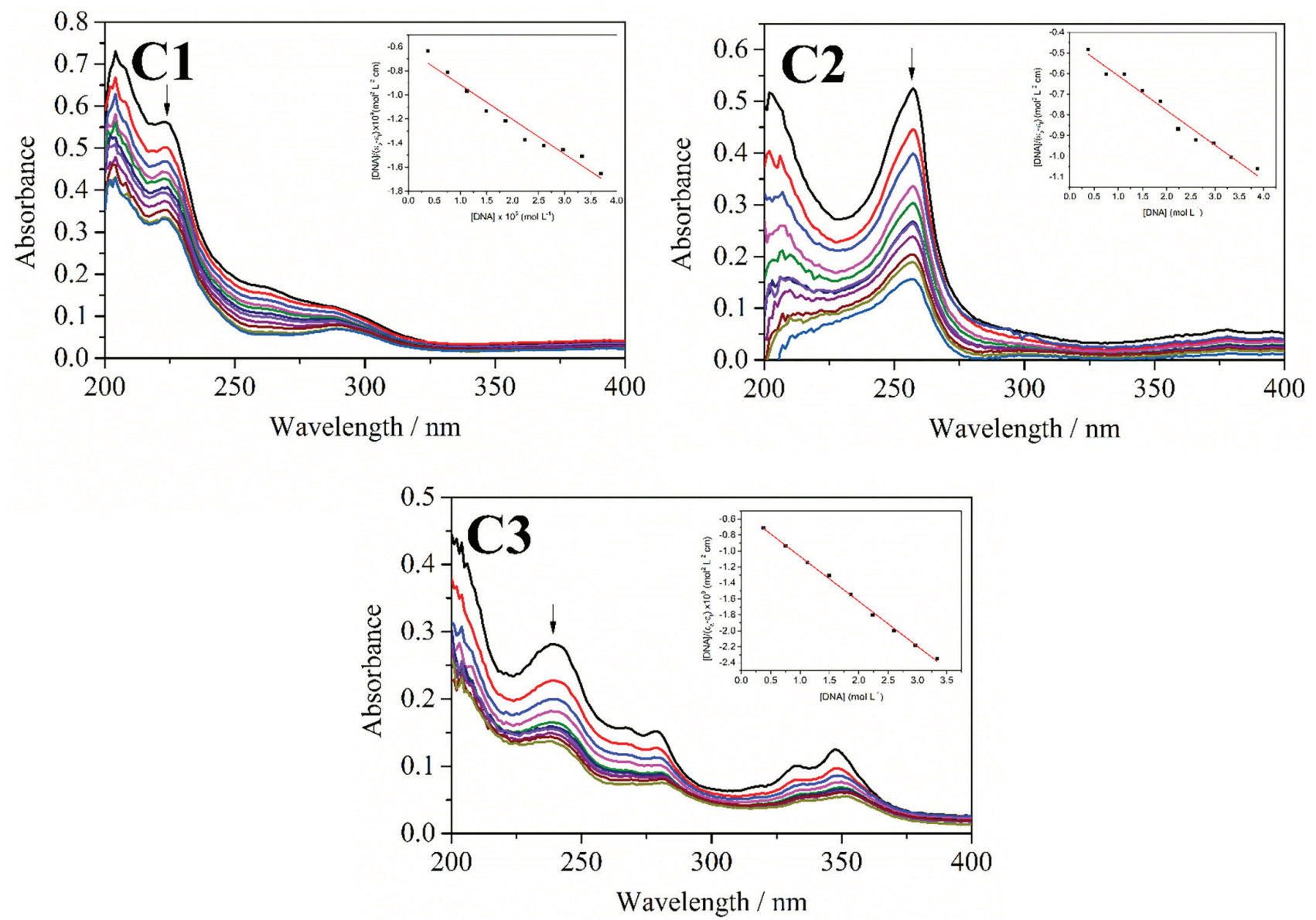

Figure 10. Spectral variation observed for complexes C1, C2 and $\mathbf{C 3}$ in the UV-Vis region with successive additions of a solution containing CT-DNA. Solvent: $\mathrm{H}_{2} \mathrm{O}$; [C] $]_{\text {intitial cuvette }}=1 \times 10^{-5} \mathrm{~mol} \mathrm{~L}^{-1}$; [TRIS-HCl $]_{\text {intial cuvette }}=0.099 \mathrm{~mol} \mathrm{~L}^{-1}$; [CT-DNA] $]_{\text {stock }}=1.89 \times 10^{-3} \mathrm{~mol} \mathrm{~L}^{-1}$. Insets: linearization of the Pyle equation to determine the interaction with CT-DNA $\left(\mathrm{K}_{\mathrm{B}}\right)$ for complexes $\mathbf{C 1}(223 \mathrm{~nm}), \mathbf{C 2}(257 \mathrm{~nm})$ and $\mathbf{C 3}(239 \mathrm{~nm})$.

Table 4. $\mathrm{K}_{\mathrm{B}}$ values determined for complexes $\mathbf{C 1}, \mathbf{C} 2$ and $\mathbf{C} 3$ at different wavelengths

\begin{tabular}{lcc}
\hline Compound & $\begin{array}{c}\text { Wavelength } \\
\text { monitored } / \mathrm{nm}\end{array}$ & $\mathrm{K}_{\mathrm{B}} /\left(\mathrm{L} \mathrm{mol}^{-1}\right)$ \\
\hline C1 & 223 & $4.59 \times 10^{4}$ \\
C2 & 257 & $3.80 \times 10^{4}$ \\
$\mathbf{C 3}$ & 239 & $1.12 \times 10^{5}$ \\
$\mathrm{H}^{52}$ & 356 & $7.4 \times 10^{4}$ \\
$\mathrm{I}^{53}$ & 310 & $3.4 \times 10^{4}$ \\
\hline
\end{tabular}

$\mathrm{H}:\left[\mathrm{Cu}_{2}\left(\right.\right.$ oxpn)(bpy)(pic) $\left.\left(\mathrm{H}_{2} \mathrm{O}\right)\right]($ pic $)$; oxpn $=N, N^{0}$-bis(3-aminopropyl) oxamide, bpy = 2,2-bipyridyl; pic = 2,4,6-trinitrophenol; $\mathrm{I}:\left[\mathrm{Cu}(\mathrm{L})_{2}\left(\mathrm{NO}_{3}\right)\right]$ $\left(\mathrm{NO}_{3}\right)\left(\mathrm{H}_{2} \mathrm{O}\right)_{1 / 2}\left(\mathrm{CH}_{3} \mathrm{OH}\right)_{1 / 2}, \mathrm{~L}=1$-[3-(2-pyridyl)pyrazol-1-ylmethyl] naphthalene; $\mathrm{K}_{\mathrm{B}}$ : DNA binding constant.

Characterizations of ligands and additional spectra and data of all complexes are available free of charge at http://jbcs.sbq.org.br as PDF file.

\section{Acknowledgments}

This study was financed in part by the Coordenação de Aperfeiçoamento de Pessoal de Nível Superior Brazil
(CAPES), finance code 001. The authors are grateful to CNPq, FINEP and INCT-Catálise and FAPESC for financial support. The authors also thank Universidade Federal de Santa Catarina (UFSC), Instituto Federal de Santa Catarina (IFSC) and Centro de Biologia Molecular (CEBIME)-UFSC.

\section{Author Contributions}

Marcos P. da Silva was responsible for investigation, writing original draft, writing-review and editing; Renata S. Heying for investigation and writing; Letícia I. da Silva for investigation and writing; Adailton J. Bortoluzzi for X-ray analysis, writing; Rosely A. Peralta for writing, project administration, visualization, review and editing; Ademir Neves for conceptualization, data curation project administration, writing and editing.

\section{References}

1. Souza, B.; Kreft, G. L.; Bortolotto, T.; Terenzi, H.; Bortoluzzi, 
A. J.; Castellano, E. E.; Peralta, R. A.; Domingos, J. B.; Neves, A.; Inorg. Chem. 2013, 52, 3594.

2. Souza, B.; Heying, R. S.; Bortoluzzi, A. J.; Domingos, J. B.; Neves, A.; J. Mol. Catal. A: Chem. 2015, 397, 76.

3. Torelli, S.; Belle, C.; Hamman, S.; Pierre, J.-L.; Saint-Aman, E.; Inorg. Chem. 2002, 41, 3983.

4. Neves, A.; Rossi, L. M.; Bortoluzzi, A. J.; Szpoganicz, B.; Wiezbicki, C.; Schwingel, E.; Inorg. Chem. 2002, 41, 1788.

5. Mouadili, A.; Attayibat, A.; El Kadiri, S.; Radi, S.; Touzani, R.; Appl. Catal., A 2013, 454, 93.

6. Posada, N. B. M.; Guimarães, M. A.; Padilha, D. S.; Resende, J. A. L. C.; Faria, R. B.; Lanznaster, M.; Amado, R. S.; Scarpellini, M.; Polyhedron 2018, 141, 30.

7. Magherusan, A. M.; Nelis, D. N.; Twamleya, B.; McDonald, A. R.; Dalton Trans. 2018, 47, 15555.

8. Solomon, E. I.; Heppner, D. E.; Johnston, E. M.; Ginsbach, J. W.; Cirera, J.; Qayyum, M.; Kieber-Emmons, M. T.; Kjaergaard, C. H.; Hadt, R. G.; Tian, L.; Chem. Rev. 2014, 114, 3659.

9. Klabunde, T.; Eicken, C.; Sacchettini, J. C.; Krebs, B.; Nat. Struct. Biol. 1998, 5, 1084.

10. Itoh, S.; Comprehensive Coordination Chemistry II, vol. 8; Elsevier: Amsterdam, 2003, p. 369.

11. Poirier, M. C.; Beland, F. A.; Kathyayini, V. D.; Damon, A. L.; Ali, M.; Vanlandingham, M. M.; Churchwell, M. I.; von Tungeln, L. S.; Dwyer, J. E.; Divi, R. L.; Beauchamp, G.; Martineau, D.; Environ. Mol. Mutagen. 2020, 61, 216.

12. Astakhova, K.; Golovin, A. V.; Prokhorenko, B. A.; Ustinov, C. A.; Stepanova, I. A.; Zatsepin, T. S.; Korshun, V. A.; Tetrahedron 2017, 73, 3220.

13. Pasternak, K.; Pasternak, A.; Gupta, P.; Veedu, R. N.; Wengel, J.; Bioorg. Med. Chem. 2011, 19, 7407.

14. Piovezan, C.; Jovito, R.; Bortoluzzi, A. J.; Terenzi, H.; Fischer, F. L.; Severino, P. C.; Pich, C. T.; Azzolini, G. G.; Peralta, R. A.; Rossi, L. M.; Neves, A.; Inorg. Chem. 2010, 49, 2580.

15. Wolfe, A.; Shimer Jr., G. H.; Meehan, T.; Biochemistry 1987, 26, 6392.

16. Camargo, T. P.; Neves, A.; Peralta, R. A.; Chaves, C.; Maia, E. C. P.; Lizarazo-Jaimes, E. H.; Gomes, D. A.; Bortolotto, T.; Norberto, D. R.; Terenzi, H.; Tierney, D. L.; Schenk, G.; Inorg. Chem. 2018, 57, 187.

17. Heying, R. S.; Silva, M.P.; Wecker, G. S.; Peralta, R.P.; Bortoluzzi, A. J.; Neves, A.; Inorg. Chem. Commun. 2019, 102, 245.

18. Lu, F.; Takaya, T.; Iwata, K.; Kawamura, I.; Saeki, A.; Ishii, M.; Nagura, K.; Nakanishi, T.; Sci. Rep. 2017, 7, 3416.

19. Fujii, A.; Sekiguchi, Y.; Matsumura, H.; Inoue, T.; Chung, W.; Hirota, S.; Matsuo, M.; Bioconjugate Chem. 2015, 26, 537.

20. Gagné, R. R.; Koval, C. A.; Lisensky, G. C.; Inorg. Chem. 1980, $19,2854$.

21. Martell, A. E.; Motekaitis, R. J.; Determination and Use of Stability Constants, $2^{\text {nd }}$ ed.; Wiley-VCH publishers: New York, USA, 1992.
22. Peralta, R. A.; Bortoluzzi, A. J.; Szpoganicz, B.; Brandão, T. A. S.; Castellano, E. E.; Oliveira, M. B.; Severino, P. C.; Terenzi, H.; Neves, A.; J. Phys. Org. Chem. 2010, 23, 1000.

23. Pettit, L. D.; Powell, K. J.; The IUPAC Stability Constants Database (Sc-Database) Academic Software, version 4.71; Otley, UK, 2008.

24. APEX2, SAINT and SADABS software, version 2011.8-0; Bruker AXS Inc., Madison, WI, USA, 2011.

25. Sheldrick, G. M.; Acta Crystallogr., Sect. C: Struct. Chem. 2015, C71, 3.

26. Spek, A. L.; Acta Crystallogr., Sect. D: Struct. Biol. 2009, D65, 148.

27. Kaizer, J.; Pap, J.; Speier, G.; Parkanyi, L.; Korecz, L.; Rocenbauer, A. J.; Inorg. Biochem. 2002, 91, 190.

28. Meyer, F.; Ackermann, J.; Kaifer, E.; Pritzkow, H.; Chem. - Eur. J. 2002, 8, 247.

29. Thoer, A.; Denis, G.; Delmas, M.; Gaset, A.; Synth. Commun. 1988, 18, 2095.

30. Amendola, V.; Fabbrizzi, L.; Pallavicini, P.; Parodi, L.; Perotti, A.; J. Chem. Soc., Dalton Trans. 1998, 12, 2053.

31. Silverstein, R. M.; Webster, F. X.; Kiemle, D. J.; Spectrometric Identification of Organic Compounds, $7^{\text {th }}$ ed.; John Wiley \& Sons: New York, USA, 2005.

32. Addison, A. W.; Rao, T. N.; Reedijk, J.; Rijn, J. V.; Verschoor, G. C.; J. Chem. Soc., Dalton Trans. 1984, 7, 1349.

33. Peralta, R. A.; Neves, A.; Bortoluzzi, A. J.; Anjos, A.; Xavier, F. R.; Szpoganicz, B.; Terenzi, H.; Oliveira, M. C. B.; Castellano, E. E.; Friedermann, G. R.; Mangrich, A. S.; Novak, M. A.; J. Inorg. Biochem. 2006, 100, 992.

34. Nakamoto, K.; Infrared and Raman Spectra of Inorganic and Coordination Compounds, $3^{\text {rd }}$ ed.; Wiley-Interscience: New York, USA, 1977.

35. Pavia, D. L.; Lampman, G. M.; Kriz, G. S.; Introduction to Spectroscopy: A Guide for Students of Organic Chemistry, $5^{\text {th }}$ ed.; Cengage Learning: Stamford, USA, 2015.

36. Neves, A.; Rossi, L. M.; Horn Jr., A.; Vencato, I.; Bortoluzzi, A. J.; Zucco, C.; Mangrich, A. S.; Inorg. Chem. Commun. 1999, $8,334$.

37. He, G.; Hua, X.; Yang, N.; Li, L.; Xu, J.; Yang, L.; Wang, Q.; Ji, L.; Bioorg. Chem. 2019, 91, 103176.

38. Zheng, P.; Eskandari, A.; Lu, C.; Laws, K.; Aldous, L.; Suntharalingam, K.; Dalton Trans. 2019, 48, 5892.

39. Jayaweera, N. P.; Hall, A. E.; Wilson, A. A.; Konkle, M. W.; Wheeler, K. A.; Semeniuc, R. F.; Inorg. Chim. Acta 2020, 506, 119507.

40. Pyle, A. M.; Rehmann, J. P.; Meshoyrer, R.; Kumar, C. V.; Turro, N. J.; Barton, J. K.; J. Am. Chem. Soc. 1989, 111, 3051.

41. Asadi, Z.; Zarei, L.; Golchim, M.; Skorepova, E.; Eigner, V. Z.; Amirghofran, Z.; Spectrochim. Acta, Part A 2020, 227, 117593.

42. Terán, A.; Jaafar, A.; Sánchez-Peláez, A. E.; Torralba, M. C.; Gutiérrez, Á.; J. Bio. Inorg. Chem. 2020, 25, 671. 
43. Joy, S. R. U.; Trufan, E.; Smith, M. D.; Puscas, C.; SilaghiDumitrescu, R. L.; Semeniuc, R. F.; Inorg. Chim. Acta 2019, 485, 190.

44. Kundu, B. K.; Ranjan, R.; Mukherjee, A.; Mobin, S. M.; Mukhopadhyay, S.; J. Inorg. Biochem. 2019, 195, 164.

45. Ahamad, M. N.; Iman, K.; Raza, M. K.; Kumar, M.; Ansari, A.; Ahmad, M.; Shahid, M.; Bioorg. Chem. 2020, 95, 103561.

46. Sheoran, M.; Bhar, K.; Jain, S.; Rana, M.; Khan, T. A.; Sharma, A. K.; Polyhedron 2019, 161, 169.

47. Sureshbabu, P.; Junaid, Q. M.; Upadhyay, C.; Victoria, W.; Pitchavel, V.; Natarajan, S.; Sabiah, S.; Polyhedron 2019, 164, 202.

48. Pereira, M. B.; Fontana, L. A.; Siqueira, J. D.; Auras, B. L.; Silva, M. P.; Neves, A.; Gabriel, P.; Terenzi, H.; Iglesias, B. A.; Back, D. F.; Inorg. Chim. Acta 2018, 469, 561.

49. Ghosh, A. K.; Ali, A.; Singh, Y.; Purohit, C. S.; Ghosh, R.; Inorg. Chim. Acta 2018, 474, 156.
50. Das, K.; Dolai, S.; Vojtíšek, P.; Manna, S. C.; Polyhedron 2018, $149,7$.

51. Chatterjee, A.; Yadav, H. R.; Choudhury, A. R.; Ali, A.; Singh, Y.; Ghosh, R.; Polyhedron 2018, 141, 140.

52. Song, Y. L.; Li, Y. T.; Wu, Z. Y.; J. Inorg. Biochem. 2008, 102, 1691.

53. Chen, R.; Liu, C. S.; Zhang, H.; Guo, Y.; Bu, X. H.; Yang, M.; J. Inorg. Biochem. 2007, 101, 412.

54. Carreira-Barral, I.; Riopedre-Fernández, M.; Blas, A.; Mosquera, J.; Vázquez, M. E.; Platas-Iglesias, C.; EstebanGómez, D.; J. Inorg. Biochem. 2020, 205, 110995.

55. Anupama, B.; J. Mol. Struct. 2020, 1210, 127988.

56. Nunes, P.; Marques, F.; Cavaco, I.; Pessoa, J. C.; Correia, I.; Inorg. Chim. Acta 2020, 507, 119558.

Submitted: September 19, 2020 Published online: December 22, 2020 